\title{
Understanding Transfer Students
}

\author{
Michelle Mouton
}

The number of transfer students attending four-year institutions is increasing rapidly, making this group of students an important segment of the campus population (Cuseo, 2003). It is important to know the history and characteristics of this population of students in order to understand how developmental theories can be applied to them. The information collected from interviews with transfer students at one public research university reflects their experiences, and the study offers suggestions to make the transfer experience a more positive one for these students.

\section{Literature Review}

Cuseo (2003) notes that today, more two-year college students will be able to make the transition to four-year institutions than at any other time in our nation's history. Because of the many benefits of attending a two-year college, such as location and cost, many students are taking advantage of their local two-year institutions as a means to reach a four-year degree. As a result, the need for understanding transfer students and their unique needs is important for university administrators, faculty, and student affairs professionals. There are several types of transfer students: (a) vertical transfers, who transfer from a two-year to a four-year institution, (b) horizontal transfers, who move from one four-year institution to another, and (c) reverse transfers, who move from a four-year institution to a two-year institution (Ward-Roof, Kashner, \& Hodge, 2003). Although they face different kinds of institutional changes, transfer students have similar characteristics and deal with the same kinds of challenges.

Transfer students have different experiences than native students - those who begin and end at the same four-year institution. In a recent report, Kuh (2004) describes several characteristics of transfer students and how they compare with native students. He found that transfer students rarely interact with faculty outside of class and do much less community service or volunteer work in college than do native students. The lifestyle of transfer students also often differs from that of native students. Transfers typically have more commitments outside the classroom, such as full-time jobs or families (Kuh, 2004).

Transfer students often are treated the same way as first-year students as they apply for and enter college, but their needs are not the same. Because transfer students are typically older, they come to a four-year institution with as much as two years of academic credit and more life experiences than do typical first-year students. They may have mastered more developmental tasks than traditional first-year students because they

Michelle Mouton (mmouton811@yahoo.com) is a Graduate Assistant for Editorial Projects at the University of South Carolina. 
already have made an initial adjustment to college, perhaps mastering study skills, time management, and budgeting (Milville \& Sedlacek, 1995).

Transfer students typically face barriers when transferring from one school to another that first-year (native) students do not. Many of these students struggle with curricular, residential, financial aid, and registration procedures (Ward-Roof et al., 2003). These students sometimes receive poor advising in the transfer process, making their transitional period more confusing and stressful (Cuseo, 2003). Additionally, transfer students are sometimes the last to register for classes and are the last to be considered for on-campus residential options (Laanan, 2001; Cuseo, 2003).

This study explored several specific transition issues and how they related to transfer students' progression into a four-year college. The information collected from interviews with transfer students at one public research university reflects the experiences of these students. This in-depth look at their transition period also leads to recommendations for institutions to make this process a more positive one for this group of students.

\section{Method}

\section{Interview Procedure}

To understand more about transfer students and their experiences, the researcher interviewed four students at a comprehensive, public research university with an enrollment of 25,000, 17,000 of whom are undergraduates. The interviews were conducted one-on-one during the spring semester of the transfer students' first year at the new university. A general beginning question was asked in order to identify the major problems faced in the transition process. The students also were asked to describe their experiences with the campus services of orientation, financial aid, and university housing, three areas that are commonly mentioned in the literature about transfer student adjustment. The purpose of this study was to gain insights into the transfer process and the students' needs. The list of prepared questions used is included in the Appendix; follow-up questions were asked as needed.

\section{Description of Participants}

Participants in the study were identified from a list of all students enrolled in the transfer section of the new-student course, University 101, in the fall of 2003. The researcher used a snowball sampling technique, asking students in the class to identify other transfer students. Of those interviewed, one was a transfer from a community college and three were transfers from other four-year institutions. Two transferred from out of state, and three were enrolled in the University 101 course for transfer students in their first semester at the new university. A more detailed description of each student is included below.

Stephanie attended a public four-year university in another state and transferred 
because her father received a position at the public research university where she now attends. Excited about transferring, she was enrolled in the University 101 program in the first semester of her sophomore year.

Jessica also transferred at the start of her sophomore year. She previously attended a smaller four-year university before transferring to this university. She also enrolled in University 101 in her first semester and joined a sorority.

Taylor spent her first two years of higher education at a community college near her home town. She had planned from the beginning to transfer to this university - the institution from which both of her parents graduated. She spent the first semester of her junior year in the University 101 course at the new university as she began taking courses toward her degree in English.

Kelly transferred from a public four-year institution in another state after her junior year. She had been very active in the cross country team there, and was reluctant to leave. She transferred to this institution because her father lived near it. She is now an Interdisciplinary Studies major and is active in ROTC.

\section{Results}

The students interviewed listed obstacles faced during the transition process that were very similar to those reported in other research. They also discussed challenges they faced with the offices this study focused on-orientation, financial aid, and university housing. Additionally, the students shared information about their engagement in coursework and their sense of belonging and attachment to the university.

\section{University Offices}

Orientation. All of the students attended an orientation program in the summer prior to starting at the public research university. The transfer orientation session is a one-day orientation to the campus, while the first-year orientation is an overnight program. Stephanie felt that this university's transfer orientation was better than the new student orientation she received at her previous institution. She liked that it gave specific information about what the campus and university were like rather then focusing on college success tips. Taylor also found the transfer orientation to be helpful. She liked that it only lasted one day and that it "didn't waste her time." She found it to be informative and beneficial to her transition. Jessica attended the new student orientation prior to beginning classes. She enjoyed it, saying, "It was intimidating at first because I didn't know anyone, and I was there by myself. But I stayed overnight and made new friends there, and I learned a lot of good stuff."

Financial Aid. These students noted difficulties with the financial aid process. Jessica stated that it was difficult to get correct information and that she was unable to transfer her scholarship when she came to the new institution. Kelly also struggled with financial aid. Because she came from out of state, her process was more complicated, and she was displeased with the service and assistance at the financial aid office. 
University Housing. Because transfer students often are notified of admission to the university after the priority deadline for applying for on-campus housing has passed, they are often left with few, if any, options. Jessica's situation was one common to most transfer students on this campus. She found that all the residence halls were full when she applied, and that finding off-campus housing was also difficult. In a somewhat unique experience, Stephanie did receive a housing assignment in a residence hall on the south end of campus. She realized she was fortunate to be in this situation and said, "I know most of the others who transferred couldn't get a spot. I was just lucky, I guess."

\section{Campus Engagement}

As Kuh (2004) suggested, transfer students are less engaged in their courses than native students. The students interviewed reported positive experiences with their professors, but noted that these were mostly limited to in-class contact. None reported participating in out-of-class activities or visiting a professor's office.

Becoming connected to the campus involves more than just academics. Most of the students felt that they did not have a strong sense of attachment to their original institution. Stephanie said she felt that there was no school spirit at her previous institution, but added that at this university, "Everyone likes showing spirit. It's fun to be involved here." Stephanie had no problem fitting in. She said, "I'm a really outgoing person, so it was easy for me to make friends with people in my classes and residence hall."

Jessica commented that although she feels comfortable at this university now that she is in her second semester, she struggled in the beginning. She said, "The first semester felt like I was in a holding pattern. I didn't know what was going on, and I didn't know what I wanted to do." She admitted that the campus was very intimidating when she began. However, she soon found friends in her sorority and began to feel a sense of school spirit and attachment to the university as she bonded with new friends. Jessica added that even now, most of her friends are also transfer students - even ones she met outside of the University 101 course. "We just sort of bond when we meet each other," she said of her experiences with meeting and befriending other transfer students.

\section{Analysis}

The students interviewed, although having struggled through some aspects of the transition process, had relatively smooth transitions when compared with some of the national trends. This may be due in part to the fact that three of them were enrolled in the University 101 transfer section, which may have helped to provide support and strong role models for the students. Participating in this first-semester course geared specifically toward transfer students and their needs may have played a role in the students' success at the receiving university. As Jessica mentioned in her interview, even now the majority of her friends are transfer students. As with native students, transfer students have an interest in finding students who are like them and who have had 
similar experiences.

Another element in a successful transition process may have to do with how the student handles the transition. Schlossberg, Waters, and Goodman (1995) state that the degree to which a transition is anticipated can play a role in the students' adjustment process. The way in which transfer students cope with these transitions can also help to determine how successful they will be. The authors identified four factors that affect how people cope with situations: situation, self, support, and strategies.

For transfer students, the situation can play an important role. For example, since Kelly's original college plan did not include a transfer, she was unhappy about it and was less willing to seek out ways to connect to the campus. She admits that she didn't really give it a chance because she was still focused on her original institution.

The students' perception of themselves also plays a part in the ease of the transition. Self-confidence is important in any transition, as is a positive outlook and a commitment to their decision (Schlossberg et al., 1995). Stephanie, who looked forward to her transfer, actively made new friends, participated in campus events, and had a relatively positive transfer experience. She also stated that she was outgoing and felt comfortable meeting new people and making friends. Her self-concept perhaps helped her to adjust quickly and enjoy her first semester.

The support transfer students receive is also important in their transition. Taylor stated that her entire family had graduated from this university and that they were happy that she would be able to do the same. This support probably helped her to persist. However, the institutional support received also plays a large role in the transition process for transfer students. All of the students interviewed mentioned difficulties with several different aspects of the university. Their transitions may have been smoother had the institution provided more support for them.

By using different strategies, students can cope with the situation in ways that suit them best. Jessica was intimidated by the large size of the campus. By joining a sorority, she found that having a group of people she knew and interacted with made the campus feel smaller and helped her become more connected to the university. The strategy of modifying her situation worked for Jessica. For Kelly, joining ROTC proved to be helpful. It is important for transfer students to find strategies that work best for them when going through the transition process.

\section{Recommendations}

Based on the students' responses, it became evident that the university can do more to improve the services provided to transfer students. When students are enrolled in the receiving institution, steps should be taken to ensure that the unique needs of this group of students are being met.

Special transfer sections of orientation/transition courses proved beneficial for the students in this study. Tailoring programs to meet the needs of transfer students is one way institutions can assist in the transition process. For example, many transfer students appreciate the special attention and close contact that comes from an orientation course 
and can benefit from programs designed to meet their needs. Curriculum topics such as career development and creating a network of faculty and students within one's major could be more tailored to their transition and academic needs. If these courses stemmed from the transfer sessions of orientation, a seamless transition could be achieved more easily. Additionally, transfer orientations should be created to focus on the needs of these students as they differ from first-year students.

Making special arrangements to provide on-campus housing for transfer students would also help provide them with a better transfer experience. Living on campus helps students to be more involved in campus, to feel connected to other students, and to succeed academically (Pascarella \& Terenzini, 1991). Reserving areas of housing specifically for transfer students, who may be applying later in the year, would help to assure them living space on campus. Stephanie mentioned that she had a very positive experience, had easy access to information, and made friends quickly because she lived on campus. If more transfer students had this opportunity, their transition might be made easier.

Additionally, financial aid programs might be able to reach this group of students by working with local sending institutions to create workshops for interested prospective transfer students. Making information easily accessible over the Internet could also assist transfer students who may not be able to visit or call during regular office hours. Finding creative ways to meet the needs of transfer students would greatly assist them through the transition period.

Although the students interviewed took some initiative and became involved on campus, this may not be the case for all transfer students. Helping these students engage in campus life should also be an important goal. Organizations like Tau Sigma, an honor society specifically for transfer students, can provide them with a welcoming environment. It also allows transfer students to make friendships, connect to campus, hold leadership positions, and develop a sense of pride in the institution and themselves. This can be a step for students to find out more about other campus groups and continue their involvement (Colquitt, 2001). Creating avenues that provide transfer students with access to information about on-campus events and services would increase their likelihood of spending more time on campus and utilizing the resource available to them.

\section{Limitations}

This study provides a snapshot of what the transition process is like for transfer students. By speaking with students individually, more detailed and personal information about their transition and development was able to be explored. However, since the sample size was small, all female, and limited to one public research university, the findings in this study may not be generalized to all transfer students. Further research should be done to determine if gender or the size of the receiving institution affects the transition process. 


\section{Conclusion}

Transfer students are a unique group of college students, and they are a group that continues to grow. They need access to many of the same services that first-year students do, but they often need to receive them in different ways because of the differences in experiences, lifestyles, and development.

Receiving and sending institutions should work together to ensure smooth transitions for transfer students. Four-year institutions should also provide more resources for this growing population of students in order to ensure their success academically and socially. As institutions make strides to assist transfer students throughout the entire process, transfer students will be able to transition more smoothly. This will enable them to become integrated into the institution quickly and persist through graduation.

\section{References}

Colquitt, L. L. (2001, Spring). Tau Sigma eases transition at Auburn. Newsletter of the National Resource Center for The First-Year Experience and Students in Transition, $13,4,7$.

Cuseo, J. (2003, November). The transfer transition. Session presented at the National Conference on Students in Transition, Lake Buena Vista, FL.

Kuh, G. (2004, January). Enhancing transfer student success. Session presented at the annual meeting of the Institute for the Study of Transfer Students, Denton, TX.

Laanan, F. S. (2001). Transfer student adjustment. New Directions for Community Colleges, 114, 5-13.

Milville, M. L., \& Sedlacek, W. E. (1995). Transfer students and freshmen: Different or parallel experiences? NASPA Journal, 32(2), 145-152.

Pascarella, E. T., \& Terenzini, P. T. (1991). How college affects students. San Francisco: Jossey-Bass.

Schlossberg, N. K., Waters, E.B., \& Goodman, J. (1995). Counseling adults in transition: Linking practice with theory (2nd ed.). New York: Springer.

Ward-Roof, J. A., Kashner, P., \& Hodge, V. (2003). Orienting transfer students. In J. A. Ward-Roof \& C. Hatch (Eds.), Designing successful transitions: A guide for orienting students to college (2nd ed., pp. 97-107, Monograph No. 13). Columbia, SC: National Resource Center for The First-Year Experience and Students in Transition (University of South Carolina). 


\section{Questions Asked During Interview of Transfer Students}

- What is your hometown?

- What is your age?

- Where did you begin your college career?

- What year did you transfer?

- Why did you transfer to USC?

- What is your major?

- Explain any major problems you faced during the transition process, if any.

- Did you have adequate access to information?

- Did you attend transfer orientation? If so, how would you describe your experience?

- Were you able to receive financial aid when you transferred?

- Describe your experiences, if any, with the financial aid office during the transition process.

- Were you interested in on-campus housing? If so, were you able to apply for it?

- Describe your sense of attachment or belonging to your first institution.

- Describe your sense of attachment or belonging at USC.

- Describe any experiences you had with faculty members, both in and out of the classroom.

- Were you able to make friends and find a social group at USC quickly?

- How did your friends and family react to your transfer? 